\title{
PEMBERDAYAAN PEREMPUAN DAN KESEHATAN MASYARAKAT
}

Oleh:

\section{WIDA SILVIA}

\section{Program Studi Kesehatan Masyarakat Universitas Faletehan}

\section{Pendahuluan}

Pembangunan kesehatan diperlukan upaya peningkatan pemberdayaan masyarakat bidang kesehatan. Pemberdayaan Masyarakat Bidang Kesehatan merupakan proses untuk meningkatkan pengetahuan, kesadaran dan kemampuan individu, keluarga serta masyarakat untuk berperan aktif dalam upaya kesehatan yang dilaksanakan dengan cara fasilitasi proses pemecahan masalah melalui pendekatan edukatif dan partisipatif serta memperhatikan kebutuhan potensi dan sosial budaya setempat. (Permenkes RI,2019)

Kesehatan masyarakat akan dapat menyelesaikan masalah kesehatan diantaranya terkait Health Empowerment untuk dapat hidup sehat secara mandiri, Health Enhancement atau melakukan upaya agar kesehatan suatu masyarakat dapat menjadi lebih baik lagi, Health Protection atau melindungi masyarakat dari berbagai masalah kesehatan dengan tersusunnya berbagai peraturan yang melindungi masyarakatnya seperti misalnya Healthy Cities, dan Health Preservation atau melestarikan hal-hal yang sudah mendukung kearah terciptanya kesehatan.

\section{Hasil Kajian}

Kegiatan Pemberdayaan perempuan dibidang gizi keluarga. Pembangunan Kesehatan Periode 2015-2019 adalah Program Indonesia Sehat dengan sasaran "Meningkatkan derajat kesehatan dan status gizi masyarakat melalui melalui upaya kesehatan dan pemberdayaan masyarakat yang didukung dengan perlindungan finansial dan pemeratan pelayanan kesehatan”.

Perilaku pemanfaatan pelayanan gizi pada ibu hamil dengan risiko KEK paling dominan dipengaruhi oleh dukungan suami dan kebutuhan (need) dan pendapatan keluarga. ibu hamil dengan risiko KEK yang tidak memperoleh dukungan suami berisiko sebanyak 6, 31 kali lebih berisiko untuk tidak memanfaatkan pelayanan gizi dibandingkan ibu hamil dengan risiko KEK yang memeroleh dukungan suami.(Hayat, Arifiati, et al., 2021)

Kegiatan Pemberdayaan perempuan dibidang keamanan bahan pangan. Hasil penelitian menunjukkan dari 43 sampel tahu di pasar tradisional Kota Serang, sebanyak 29 sampel tahu 
$(67,4 \%)$ positif mengandung formalin. Pengetahuan $(\mathrm{p}=0,016)$ dan pengawasan $(\mathrm{p}=0,004)$ dengan penggunaan formalin pada pedagang tahu. Penegakan aturan, pembinaan pedagang dan produsen tahu mencegah penggunaan formalin. (Hayat \& Darusmini, 2021) Pendidikan kesehatan cuci tangan efektif untuk meningkatkan pengetahuan dan keterampilan tentang teknik cuci tangan.(Hayat, 2021)

Kegiatan Pemberdayaan perempuan dibidang pencegahan dan pengendalian penyakit berbasis vektor. Kegiatan pemberdayaan masyarakat dalam upaya pencegahan dan pengendalian DBD. Edukasi Pemberantasan Sarang Nyamuk (PSN) 3M Plus efektif dalam meningkatkan pengetahuan. (Hayat, Nurdiawati, et al., 2021) Penemuan kasus secara dini dan pengobatan secara cepat dapat dilakukan dengan peran serta masyarakat.(Hayat \& Kurniatillah, 2009)

Kegiatan Pemberdayaan perempuan dibidang pencegahan dan pengendalian limbah bahan berbahaya. Praktik pengelolaan limbah dilakukan dengan memperkuat pengetahuan, sikap yang baik.(Hayat, 2015) Faktor enabling seperti ketersediaan dana dan sarana berpengaruh terhadap praktik keselamatan kerja pegelolaan limbah yang baik.(Hayat, 2012)

Kegiatan Pemberdayaan perempuan dibidang pencegahan dan pengendalian pencemaran lingkungan. Kondisi kualitas air sungai Cibanten dalam tercemar sedang. Dalam beberapa situasi, persyaratan dan kebijakan yang lebih ketat diperlukan untuk mencapai keberlanjutan kualitas air dan ekologi di Provinsi Banten. (Hayat \& Kurniatillah, 2021) Pencemaran air oleh kadar klor bebas $(\mathrm{Cl} 2)$ rata-rata sebesar $0.28 \mathrm{mg} / \mathrm{L}-0,335 \mathrm{mg} / \mathrm{L}$ terjadi di Sungai Cidanau berdampak pada kesehatan masyarakat.(Hayat, 2020)

\section{Daftar Pustaka}

Hayat, F. (2012). Pengaruh predisposing factor, Enable factor, Reinforcing factor terhadap praktik keselamatan kerja pada tenaga kesehatan dalam pengelolaan limbah medis padat di Puskesmas Wilayah Kota Cilegon tahun 2011. In Unpad Repository. Unpad.

Hayat, F. (2015). Analisis faktor pengelolaan limbah medis padat di Rumah Sakit Umum Daerah Kota Cilegon. Faletehan Health Journal, 3, 146-151.

Hayat, F. (2020). Analisis Kadar Klor Bebas (C12) dan Dampaknya Terhadap Kesehatan Masyarakat di Sepanjang Sungai Cidanau Kota Cilegon. Jurnal Kesehatan Masyarakat Mulawarman (JKMM), 2(2), 64-69.

Hayat, F. (2021). THE EFFECT OF EDUCATION USING VIDEO ANIMATION ON ELEMENTARY SCHOOL IN HAND WASHING SKILL. Acitya: Journal of Teaching and Education, 3(1), 44-53. 
Hayat, F., Arifiati, N., \& Permatasari, T. A. E. (2021). Peran Dukungan Suami dan Faktor Lainnya terhadap Pemanfaatan Pelayanan Gizi oleh Ibu Hamil dengan Risiko Kurang Energi Kronis (KEK). Jurnal Keperawatan Silampari, 5(1), 125-133.

Hayat, F., \& Darusmini, D. (2021). ANALISIS FAKTOR PENGGUNAAN FORMALIN PADA PEDAGANG TAHU DI PASAR TRADISONAL KOTA SERANG. Jurnal Surya Muda, 3(2), 121-132.

Hayat, F., \& Kurniatillah, N. (2009). Situasi Malaria di Kabupaten Lebak. Kesmas: Jurnal Kesehatan Masyarakat Nasional (National Public Health Journal), 3(6), 259-263.

Hayat, F., \& Kurniatillah, N. (2021). Microbiological and Water Quality Status of Cibanten River. The First International Conference on Social Science, Humanity, and Public Health (ICOSHIP 2020), 198-200.

Hayat, F., Nurdiawati, E., \& Kurniatillah, N. (2021). EDUKASI GERAKAN PEMBERANTASAN NYAMUK (PSN) DEMAM BERDARAH PADA ANAK USIA SEKOLAH DASAR DI KECAMATAN JAWILAN KABUPATEN SERANG.

Peraturan Menteri Kesehatan Republik Indonesia Nomor 8 Tahun 2019 Tentang Pemberdayaan Masyarakat Bidang Kesehatan 